The Review of Finance and Banking

print ISSN 2067-2713, online ISSN 2067-3825

Volume 12, Issue 1, Year 2020

http://dx.doi.org/10.24818/rfb.20.12.01.04, Pages 49-62

\title{
EFFECTS OF MERGER AND ACQUISITION ANNOUNCEMENTS ON STOCK RETURNS: AN EMPIRICAL STUDY OF BANKS LISTED ON NSE AND NYSE
}

\author{
DHAREN KUMAR PANDEY* AND VINEETA KUMARI
}

\begin{abstract}
We use the event study method to examine the merger and acquisition announcement effects on the stock returns of the sample of 14 acquiring banks from India and the United States (US). The study concludes that although different markets react differently, such news does impact the stock price reaction by generating some abnormal returns around the announcement date. Since the cumulative average abnormal returns (CAARs) on most of the days in the event window period, as well as the post-event-window period, are significant for the shares of the Indian acquiring banks, the Indian market, an emerging market is more sensitive to such information as compared to the US market, a developed one.
\end{abstract}

\section{INTRODUCTION}

Businesses strive for the perfect strategy. Many business units use merger and acquisition strategy to eliminate competition and create synergy. However, researchers have continuously tried to find whether the bidder or the target firms benefit from it. Many studies including Song \& Walking (2000), Campa \& Hernando (2005), Diaw (2011), Selcuk (2015), and, Chen, Ramaya $\& \mathrm{Wu}(2019)$ find that the merger announcements have benefited the shareholders of the target firms while the acquiring firms experience either a negative or zero abnormal return. This business strategy is used in all the industries and the banking sector is not an exception. Since the global recession in late 2008, which developed due to the failure of the banking industry, banks have started implementing strategies that make them more liquid. In this study, we find pieces of evidence for the impacts of merger and acquisition announcements on stock returns of acquiring banks in different markets. To develop further insight we review some of the available literature in the next section.

1.1. Event Studies on mergers and acquisitions. Song \& Walking (2000) examined a sample of 470 target firms listed on the Value Line for the period from 1982 to 1991 and found that the abnormal returns of the target firms are positive and significant. Wilcox, Chang \& Grover (2001) examined 44 mergers and acquisitions in the telecommunications sector in the US using the event study method to study the impact on the firm's value and concluded that larger firms experience greater valuation effects. Perepeczo (2007) has discussed the problems of abnormal returns and the models for calculating expected returns along with some examples of post-acquisition impacts in developed markets. Gopalaswamy, Acharya \& Malik (2008) examined the impact of merger announcements on stock prices of 25 firms during the period 2000-2007 using the multiple event window method and concluding the semi-strong efficiency

Received by the editors April 22, 2020. Accepted by the editors June 2, 2020.

Keywords: Event study, merger and acquisition, abnormal returns, market model.

JEL Classification: G14; G15; G34.

*Dharen Kumar Pandeya, PhD, corresponding author, Assistant Professor, P.G. Department of Commerce, Magadh University, Bodh Gaya, Bihar, India. E-mail: dharenp@gmail.com.

Vineeta Kumari, MBA, Assistant Professor, P.G. Department of Commerce, Magadh University, Bodh Gaya, Bihar, India. E-mail: vidhatamu@gmail.com.

This paper is in final form and no version of it will be submitted for publication elsewhere. 
of the Indian stock market. Oler, Harrison \& Allen (2008) with a sample of 2500 horizontal mergers from 1975-1999 concluded that the market reactions are positive initially but in the long run, the post-acquisition returns are negative. They concluded that short window studies fail to accurately measure the economic impact of strategic decisions. Duso, Gugler \& Yurtoglu (2010) compared the stock market data and the accounting data of 482 firms for the period 1990-2002 to examine whether event study methodology is useful for merger analysis to conclude that with the use of long window around the event the ex-post-merger effect is best captured.

Shah \& Arora (2014) examined the announcement effects of 37 mergers and acquisitions in the Asia-Pacific market using the event study method and Corrado (2010) test and found that the cumulative average abnormal returns of the bidders were not statistically significant. Adnan \& Hossain (2016) examined the stock price behaviour of 50 bidders and 50 targets US firms to the mergers and acquisitions (M\&As) announcement using $-5,+5$ event window and found that the cumulative average abnormal returns (CAARs) before announcements follow an upward trend while those after announcement follow a downward trend indicating information leakage and anticipation. Selcuk (2015) analysed the data of 67 Turkish firms to find the impact of merger announcements on stock price behaviour of the target firms for the period from 2000-2014 using 21 days window around event date and conclude that target firms accrue the benefits of M\&As. Sachdeva, Sinha \& Kaushik (2015) examined 85 merger and acquisition announcements during 1991-2010 to study the impact on the bidding firm's shareholder's wealth and found negative average abnormal returns (AARs) immediately after the announcement day. The post-merger performance was found negative. Sylvani \& Yunita (2017) examined the merger and acquisition effects of 17 telecommunication firms in Asia-Pacific using $-10,+10$ event window and found no significant AARs and average volatility abnormal returns (AVARs) concluding it a semi-strong efficient market. Yilmaz \& Tanyeri (2018) examined 3-day cumulative abnormal returns (CARs) for 2,63,461 merger deals in 47 countries for the period 1992-2011 using Brown \& Warner (1985) and found that the 3-day CARs are significant for both bidders as well as targets; higher CARs for developed markets as compared to emerging markets. They also found information leakage in the emerging markets. Chen, Ramaya \& Wu (2019) studied the impact of announcements on the daily bond prices analysing the data of 5052 and 1057 bonds of acquiring and target firms respectively using the bond event study methodology and found that the acquirer's bondholders experience negative abnormal returns while the target firm bondholders experience positive abnormal returns. Farinos, Herrero \& Latorre (2019) examined the Spanish listed bidding firm's short and long-term performance in response to acquisition announcements during the period 1991-2016 with a sample of 146 acquisitions using the event study method and concluded that the investor behaviour in the Spanish market is not irrational as seen in markets of the US and the United Kingdom (UK).

1.2. Event Studies on mergers and acquisitions in the banking sector. Campa \& Hernando (2005) examined the impact of M\&As in the European Union financial industry with a sample period from 1998-2002 and a sample size of 172 transactions. They found that the shares of the target firms earned positive abnormal returns while those of the acquirer had zero excess returns. They also find that in the long run after one year of such announcements; the excess returns of the target firms are negative but non-significant from zero. Diaw (2011) studied the announcement effects of the mergers and acquisitions of 97 European banks for the period 1997-2008 and found that the value created by the bidder is reaped by the shareholders of the target firms; though shareholders of bidding banks are not harmed. Shah \& Deo (2013) studied the impact of merger events on the behaviour of the stock prices in the Indian banking sector with a sample size of 17 merger announcements using the ordinary least squares (OLS) and the constant market model and concluded that merger events had no significant impact on bidding bank. Also, the private sector banks experienced the most of the negative average abnormal returns. Antoniadis, Alexandridis \& Sariannidis (2014) examined the announcement effects on the share prices of 3 Greek banks (1 bidder and 2 targets) using the event study 
methodology and the results supported the efficient market hypothesis. Rehman, Ali \& Zebran (2018) analysed a data of 11 mergers and acquisitions in the Pakistan's banking sector during 2002-2012 to find their effects on stock price behaviour using the market study method and found mixed behaviour of stock prices over different events. Kumara, Vidhya \& Reddy (2019) examined a sample 2 private and 2 public Indian bank mergers to investigate the impacts of merger announcements on pre and post-announcement stock prices using event study method and conclude that the merger announcements have no significant impact on the closing prices for any of the banks.

The literature review of event studies examining the impacts of mergers and acquisitions announcements on the stock price behaviour reveals that a few studies have been conducted on the mergers in the banking \& financial sector, for example, Campa \& Hernado (2005), Diaw (2011), Shah \& Deo (2013), Antoniadis, Alexandridis \& Sariannidis (2014), Rehman, Ali \& Zebran (2018), and, Kumara, Vidhya \& Reddy (2019). However, no event study has compared the impacts on two different markets; although Yilmaz \& Tanyeri (2018) is a comparison of developed and emerging markets and Farinos, Herrero \& Latorre (2019) compared the results with different markets: both studies are not on the banking sector.

It is evident from the literature review in section 1.1 and 1.2 that the impact of the merger announcements on the stock prices of the acquiring firms are negative and significant as almost all the studies have concluded. This study examines the data of the acquiring banks in two markets, viz., India, the emerging market and the US, the developed market, to compare the inferences drawn in the available literature.

\section{Objectives, Data Colleciton and methodology}

2.1. Objectives of the study. This paper aims to study the impacts of the announcement news bank mergers and acquisitions on the stock prices of the acquiring banks. To study the impacts on stocks of the banks, the behaviour of the stock prices both before and after the announcement date has been analyzed. The null hypothesis that "abnormal returns on and around announcement dates are less than or equal to zero", implicates that M\&As announcements had no impact on banking sector stocks. If, the null hypothesis is rejected the study will conclude that the announcements had impacted the returns on the stocks of the acquiring banks.

2.2. Sample selection and data collection. The period of study is 2010-2020. A total of 8 banks M\&As took place in India which included 24 banks, 8 acquiring and 16 acquired. In the United States, 10 mergers involving 20 banks took place during the period. However, the data was available for only 8 acquiring banks because First Merit Bank, NBT Bank, Old National Bank and Huntington Bancshares were not listed on New York Stock Exchange (NYSE). Hence, the sample in the study consists of 8 banks listed on the National Stock Exchange (NSE) and 6 banks listed on the NYSE during the period of study selected by qualifying the following criteria for sample selection:

1. M\&As during the period 2010 to 2020 .

2. Acquiring banks must be listed on NSE or NYSE, as the case may be.

3. Data must be available for the study period.

The relevant data for the period of study has been collected from the NSE website and the yahoo finance website.

2.3. Methodology. The standard methodology of event study Brown \& Warner $(1980 ; 1985)$ with the market model for estimation has been used in this study. While conducting an event study, the event, the event date, the event window, the estimation window \& the estimation model are determined. The events, here, are the announcements of mergers and acquisitions and the event dates (t) are the dates of announcement as mentioned in Table1. 


\begin{tabular}{|c|c|c|c|}
\hline NSE & & NYSE & \\
\hline $\begin{array}{l}\text { Announcements } \\
\text { (Event) }\end{array}$ & $\begin{array}{l}\text { Announcement } \\
\text { (Event) Date }\end{array}$ & $\begin{array}{l}\text { Announcements } \\
\text { (Event) }\end{array}$ & $\begin{array}{l}\text { Announcement } \\
\text { (Event) Date }\end{array}$ \\
\hline $\begin{array}{l}\text { ICICI Bank acquired } \\
\text { Bank of Rajasthan }\end{array}$ & 18.05 .2010 & $\begin{array}{l}\text { M\&T Bank acquired } \\
\text { Wilmington Trust }\end{array}$ & 01.11 .2010 \\
\hline $\begin{array}{l}\text { Kotak Mahindra Bank } \\
\text { acquired ING Vysya } \\
\text { Bank }\end{array}$ & 20.11 .2014 & $\begin{array}{l}\text { Capital One acquired } \\
\text { ING Direct USA }\end{array}$ & 16.06 .2011 \\
\hline $\begin{array}{l}\text { SBI acquired its six } \\
\text { subsidiaries }\end{array}$ & 17.05 .2016 & $\begin{array}{l}\text { PNC Financial Services } \\
\text { acquired RBC Bank } \\
\text { USA }\end{array}$ & 19.06 .2011 \\
\hline $\begin{array}{l}\text { Bank of Baroda ac- } \\
\text { quired Vijaya Bank and } \\
\text { Dena Bank }\end{array}$ & 17.09.2018 & $\begin{array}{l}\text { M\&T Bank acquired } \\
\text { Hudson City Bancorp }\end{array}$ & 27.08 .2012 \\
\hline $\begin{array}{l}\text { Punjab National Bank } \\
\text { acquired Oriental Bank } \\
\text { of Commerce and } \\
\text { United Bank of India }\end{array}$ & 30.08 .2019 & $\begin{array}{l}\text { Key Bank acquired } \\
\text { First Niagara Financial }\end{array}$ & 30.10 .2015 \\
\hline $\begin{array}{l}\text { Union Bank acquired } \\
\text { Andhra Bank and Cor- } \\
\text { poration Bank }\end{array}$ & 30.08 .2019 & $\begin{array}{l}\text { BB\&T acquired Sun } \\
\text { Trust Bank }\end{array}$ & 07.02 .2019 \\
\hline $\begin{array}{l}\text { Canara Bank acquired } \\
\text { Syndicate Bank }\end{array}$ & 30.08 .2019 & & \\
\hline $\begin{array}{l}\text { Allahabad } \quad \text { Bank } \\
\text { acquired Indian Bank }\end{array}$ & 30.08 .2019 & & \\
\hline
\end{tabular}

A total of 14 announcements involve 11 event dates leading to 11 event windows and 11 estimation windows. Each event window consists of 61 days from -30 to +30 trading days. The estimation window shall be a period just before the event window. In our case, it is of 60 days from -90 to -31 trading days. The post-event window period is of 20 days $(+31$ to +50$)$. The pictorial view of the event windows is depicted in Figure 1. The estimation model for estimating the abnormal returns is the market model.

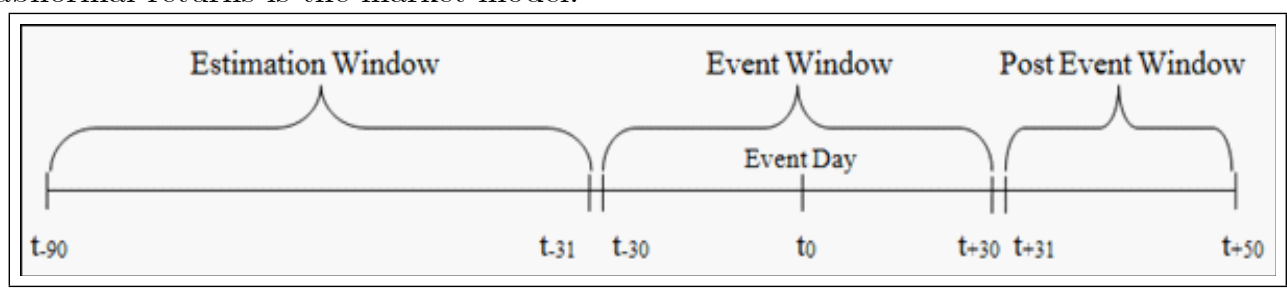

Figure 1: Event Study Model used in the study (Source: Drawn by the authors to represent the event timeline)

2.4. Calculation of abnormal returns and average abnormal returns. First of all we have to find the abnormal returns for each day in the event window. The abnormal return is calculated by subtracting the expected return from the actual return on the stock. The formula is as below:

Where,

$$
\mathrm{AR}_{\mathrm{ABt}}=\mathbf{R}_{\mathrm{ABt}}-\mathbf{E R}_{\mathrm{ABt}}
$$

$\mathbf{A} \mathbf{R}_{\mathrm{ABt}}$ is the abnormal return on acquired bank's stock $\mathrm{AB}$ on day t;

$\mathbf{R}_{\mathbf{A B t}}$ is the actual return on acquired bank's stock $\mathrm{AB}$ on day t; and, 
$\mathbf{E R}_{\mathrm{ABt}}$ is the expected return on the acquired bank's stock $\mathrm{AB}$ on day $\mathrm{t}$.

The actual return on a security is calculated by subtracting the previous day's price of a security from the price as on the day of calculation and dividing the difference by the previous day's price. To calculate $\mathbf{R}_{\mathrm{ABt}}$, the actual return on acquired bank's stock $\mathrm{AB}$ on day t, we use the formula as below:

$$
\mathbf{R}_{\mathrm{ABt}}=\frac{\mathbf{P}_{\mathrm{ABt}}-\mathbf{P}_{\mathrm{ABt}-1}}{\mathbf{P}_{\mathrm{ABt}-1}} \times 100
$$

Where,

$\mathbf{P}_{\mathrm{ABt}}=$ Price of acquired bank's stock $\mathrm{AB}$ on day t; and,

$\mathbf{P}_{\mathrm{ABt}-\mathbf{1}}=$ Price of acquired bank's stock $\mathrm{AB}$ on day before day t.

The expected return on the acquired bank's stock $\mathrm{AB}, \mathbf{E R}_{\mathbf{A B t}}$, is calculated using the following formula:

Where,

$$
\mathbf{E R}_{\mathrm{ABt}}=\alpha+\boldsymbol{\beta}_{\mathbf{j}}\left(\mathbf{R}_{\mathrm{mt}}-\boldsymbol{\alpha}\right)
$$

$\boldsymbol{\alpha}$ and $\boldsymbol{\beta}_{\mathbf{j}}$ are the intercept and slope of the regression model

$\mathbf{R}_{\mathbf{m t}}$ is the rate of return on the NIFTY or NYSE index, as the case may be, on day t.

Once the abnormal returns for each day in the event period have been calculated, the average abnormal returns of the sample are calculated by dividing the aggregated day-wise abnormal returns by the sample size. In this way, the average abnormal returns (AARs) for the acquired bank's stock $\mathrm{AB}$ are calculated using the formula below:

$$
\operatorname{AAR}_{\mathrm{ABK}}=\frac{1}{\mathrm{~N}} \sum_{\mathrm{AB}=1}^{\mathrm{K}} \mathbf{A R}_{\mathrm{ABt}}
$$

Where,

$\mathbf{A A R}_{\mathrm{ABK}}$ is the average abnormal return for acquired bank's stock $\mathrm{AB}$ for the period $\mathrm{K}$ and $\mathrm{N}$ is the sample size.

2.5. Calculation of test statistics. Once the AARs are calculated, the CAARs are calculated. Now that the cross-sectional and time-series aggregation is done and we have calculated the AARs and CAARs for the event period, we need to test for their significance. To test for significance, the t-statistics, $\mathbf{t}_{\mathbf{A A R}}$, for AARs are calculated by dividing the AARs by the aggregate estimation period standard deviation of the daily abnormal returns. The t-statistics, $\mathbf{t}_{\mathbf{C A A R}}$, for the CAARs is arrived at by dividing the CAARs by the product of the aggregate estimation period standard deviation of the daily abnormal returns and the square root of the absolute value of the event day plus 1 . The following formula is used to calculate the estimation period standard deviation of daily abnormal returns:

$$
\sigma_{\mathbf{j}, \text { est }}=\sqrt{\frac{\sum_{-90}^{-31}\left(\mathbf{A R}_{\mathrm{ABt}}-\mathbf{A A R}_{\mathrm{est}}\right)^{2}}{\mathbf{n}}}
$$

Where,

$\sigma_{\mathrm{j}, \mathbf{e s t}}$ is the estimation period standard deviation of daily abnormal returns;

$\mathbf{A A R}_{\text {est }}$ is the average abnormal return on acquired bank's stock $\mathrm{AB}$ for the estimation period; and,

$\mathrm{n}$ is the number of days in the estimation period

Now, the aggregate estimation period standard deviation, $\boldsymbol{\sigma}_{\mathbf{N}, \mathbf{e s t}}$, is calculated as follows:

$$
\sigma_{\mathrm{N}, \mathrm{est}}=\sqrt{\frac{\sum_{\mathrm{i}=1}^{\mathrm{N}} \sigma_{\mathrm{i}, \mathrm{est}}^{2}}{\mathrm{~N}^{2}}}
$$

As discussed earlier, the t-statistics for AARs and CAARs are calculated as: 
$\mathbf{t}_{\mathbf{A A R}}=\frac{\mathbf{A A R}_{\mathrm{t}}}{\sigma_{\mathrm{N}, \mathrm{est}}}$, and; $\mathbf{t}_{\mathbf{C A A R}}=\frac{\mathbf{C A A R}}{\sigma_{\mathrm{N}, \text { est }} \sqrt{\mathbf{N}_{\mathrm{t}+1}}}$, respectively.

Where,

$\mathbf{N}_{\mathbf{t}+\mathbf{1}}$ is the absolute value of event day t plus 1 (e.g. for event day -15, the absolute value is 15 and $\mathbf{N}_{\mathbf{t}+\mathbf{1}}=16$ ).

2.6. Test of significance. The test statistics obtained will now be used to test the hypothesis of the study. The null hypothesis to be tested is that "abnormal returns on and around announcements are less than or equal to zero". If the AARs are positive and significant, it indicates that the market reacted positively and the abnormal returns on the demonetization day and post-demonetization were more than those during the pre-demonetization period. If the t-test statistic is greater (in absolute value) than the critical values, the average abnormal return is statistically significant. The critical t-value for comparison is provided in table 2 .

\begin{tabular}{|c|c|c|c|c|}
\hline \multicolumn{5}{|c|}{ Table 2: Critical t values for different sample sizes } \\
\hline Sector & $\mathrm{N}$ & Degree of Freedom & \multicolumn{2}{c|}{ t-value (2-tailed) } \\
\hline & & & $1 \%$ level & $5 \%$ level \\
\hline Sample & 14 & 13 & 3.01 & 2.16 \\
\hline NSE & 8 & 7 & 3.50 & 2.36 \\
\hline NYSE & 6 & 5 & 4.03 & 2.57 \\
\hline \multicolumn{2}{|l}{ Source: Prepared by the authors on basis of values calculated at https://goodcalculators.com/student-t-value-calculator/ } \\
\hline
\end{tabular}

\section{Quantitative analysis and Discussion}

In this part we discuss the results event-wise, market-wise and that of the entire sample. The daily AARs, CAARs and test statistics for the event window as well as the post-event window period have been discussed.

3.1. Mean abnormal returns for individual events. Table 3 depicts the mean abnormal returns for each of the events.

\begin{tabular}{|c|c|c|c|c|}
\hline \multicolumn{7}{|c|}{ Table 3: Mean abnormal returns for individual events } \\
\hline Events & \multicolumn{3}{|c|}{ Mean Abnormal Returns } & Effect \\
\hline Event1-ICICI-BOR & Pre (t-30 to t-1) & Post $(\mathrm{t}+1$ to t+30) & $\%$ change & \\
\hline Event2-KOTAKMB-INGVB & -0.09 & -0.44 & -0.35 & decrease \\
\hline Event3-SBI-SUBSIDIARIES & -0.06 & 0.17 & 0.23 & increase \\
\hline Event4-BOB-VIJAYA\&DENA & -0.32 & 0.63 & 0.96 & increase \\
\hline Event5-PNB-OBC\&UBI & -0.41 & 0.04 & 0.45 & increase \\
\hline Event6-UNION-ANDHRA\&CORP & -0.19 & -0.50 & -0.32 & decrease \\
\hline Event7-CANARA-SYNDICATE & -0.37 & -0.90 & -0.53 & decrease \\
\hline Event8-ALLAHABAD-INDIAN & 0.22 & -0.36 & -0.59 & decrease \\
\hline Event9-M\&T-WILMINGTON & -0.26 & -1.30 & -1.05 & decrease \\
\hline Event10-CAPITALONE-INGDIRECT & -0.52 & 0.25 & 0.77 & increase \\
\hline Event11-PNCFS-RBC & -0.07 & -0.24 & 0.05 & increase \\
\hline Event12-M\&T-HDSONCITY & -0.04 & -0.09 & -0.02 & decrease \\
\hline Event13-KEYBANK-FIRSTNIAGRA & -0.04 & 0.16 & 0.21 & increase \\
\hline Event14-BB\&T-SUNTRUST & 0.24 & 0.35 & 0.39 & increase \\
\hline \multicolumn{2}{|c|}{ Source: Author's calculations in MS-Excel } & -0.36 & decrease \\
\hline
\end{tabular}

It can be seen that the mean abnormal return for 12 events are negative during the pre-event day period while in the post-event day period, the mean abnormal return is negative for 8 events. While the change in the mean abnormal return for the shares of Kotak Mahindra Bank, State Bank of India, Bank of Baroda, M\&T Bank (Event 9), Capital One Fin. Corp., M\&T Bank (Event 12) and Key Bank in the post-event day period as compared to the pre-event day 
period has been negative, for the shares of ICICI Bank, Punjab National Bank, Union Bank, Canara Bank, Allahabad Bank, PNC Fin. Services and BB\&T it has been positive. With equal positive and negative effects, we see a mixed response.

It is also evident that the Indian banks have experienced more negatives than the US Banks. The mergers and acquisitions in the US have yielded positive abnormal returns in the postevent day period for most of the acquiring banks. In the next section, we discuss whether these abnormal returns are significant or not.

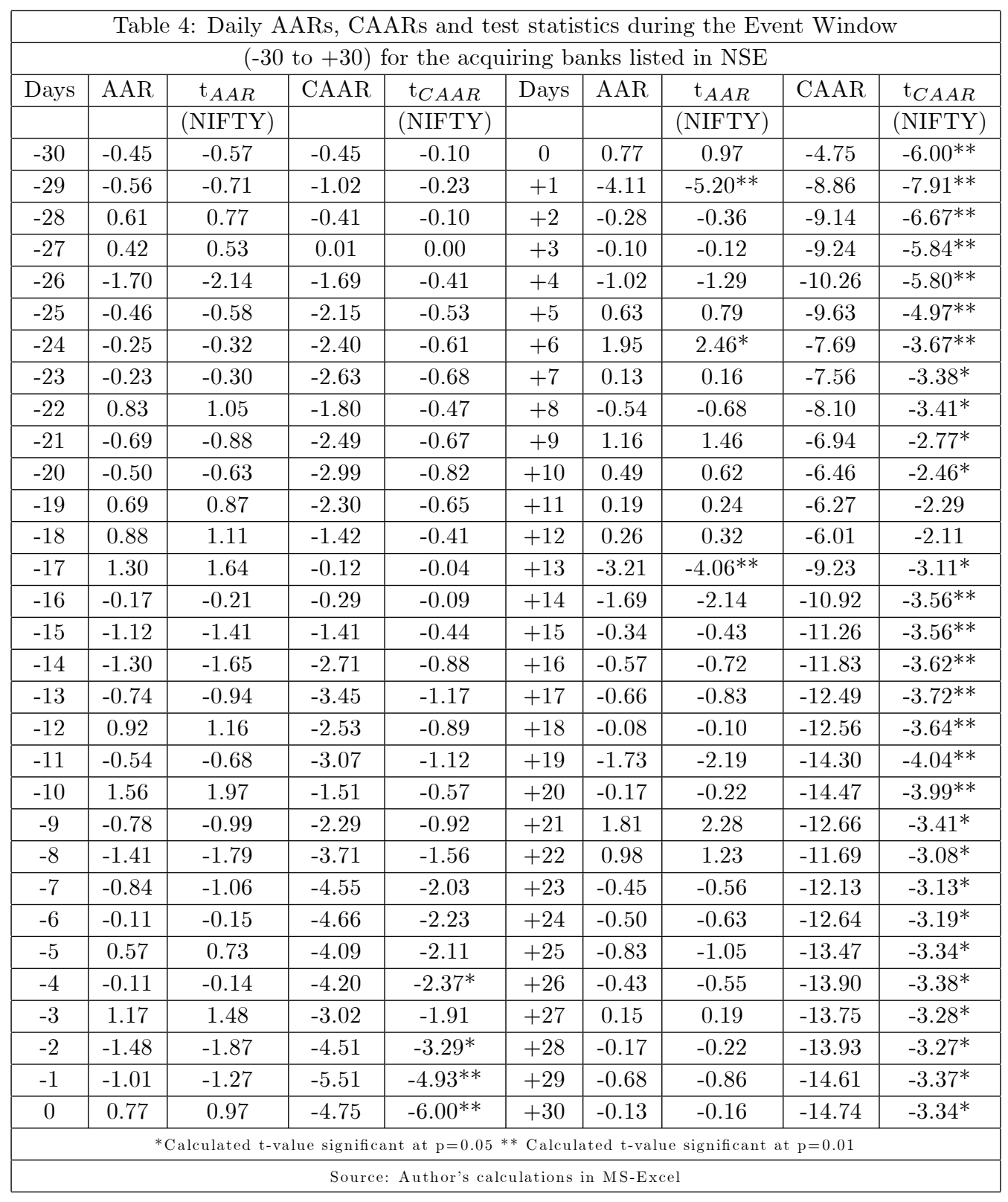

3.2. Average abnormal returns of banks listed on the NSE. Table 4 presents the daily AARs, CAARs and the test statistics for the Indian acquiring banks during the event window. The AARs are negative for 20 days each in the pre as well as post-event day period. No significant AARs during the period t-31 to t0 can be noticed while only 3 significant AARs are present during the period $t+1$ to $t+30$. Even the event day AAR is not significant. While the 
AARs on $t+1$ and $t+13$ are significant at $1 \%$ significance level, the AAR on $t+6$ is significant at a $5 \%$ significance level.

\begin{tabular}{|c|c|c|c|c|c|c|c|c|c|}
\hline \multirow{2}{*}{\multicolumn{10}{|c|}{$\begin{array}{l}\text { Table 5: Daily AARs, CAARs and test statistics during the Eve } \\
(-30 \text { to }+30) \text { for the acquiring banks listed in NYSE }\end{array}$}} \\
\hline & & & & & & & & & \\
\hline \multirow[t]{2}{*}{ Days } & \multirow[t]{2}{*}{$\mathrm{AAR}$} & \multirow{2}{*}{$\frac{\mathrm{t}_{A A R}}{(\mathrm{NYSE})}$} & \multirow[t]{2}{*}{ CAAR } & \multirow{2}{*}{$\begin{array}{c}\mathrm{t}_{C A A R} \\
(\mathrm{NYSE})\end{array}$} & \multirow[t]{2}{*}{ Days } & \multirow[t]{2}{*}{ AAR } & \multirow{2}{*}{$\frac{\mathrm{t}_{A A R}}{(\mathrm{NYSE})}$} & \multirow[t]{2}{*}{ CAAR } & \multirow{2}{*}{$\frac{\mathrm{t}_{C A A R}}{(\mathrm{NYSE})}$} \\
\hline & & & & & & & & & \\
\hline-30 & -0.05 & -0.10 & -0.05 & -0.02 & 0 & 1.02 & 2.28 & -2.70 & $-6.00 * *$ \\
\hline-29 & 0.30 & 0.66 & 0.25 & 0.10 & +1 & -0.49 & -1.10 & -3.19 & $-5.02 * *$ \\
\hline-28 & 0.66 & 1.48 & 0.91 & 0.38 & +2 & 0.88 & 1.96 & -2.31 & $-2.97^{*}$ \\
\hline-27 & 0.17 & 0.38 & 1.08 & 0.46 & +3 & 0.09 & 0.20 & -2.22 & -2.47 \\
\hline-26 & -0.18 & -0.41 & 0.90 & 0.38 & +4 & 0.15 & 0.33 & -2.07 & -2.07 \\
\hline-25 & -0.44 & -0.98 & 0.46 & 0.20 & +5 & 0.85 & 1.89 & -1.23 & -1.11 \\
\hline-24 & -0.12 & -0.26 & 0.34 & 0.15 & +6 & -0.14 & -0.32 & -1.37 & -1.15 \\
\hline-23 & 0.12 & 0.27 & 0.46 & 0.21 & +7 & 0.83 & 1.84 & -0.54 & -0.43 \\
\hline-22 & 0.35 & 0.78 & 0.81 & 0.38 & +8 & 0.31 & 0.69 & -0.24 & -0.18 \\
\hline-21 & 0.09 & 0.21 & 0.90 & 0.43 & +9 & 0.57 & 1.28 & 0.34 & 0.24 \\
\hline-20 & -0.37 & -0.82 & 0.54 & 0.26 & +10 & -0.52 & -1.16 & -0.18 & -0.12 \\
\hline-19 & -0.13 & -0.30 & 0.40 & 0.20 & +11 & -0.08 & -0.17 & -0.26 & -0.17 \\
\hline-18 & -1.37 & -3.04 & -0.96 & -0.49 & +12 & 0.14 & 0.32 & -0.12 & -0.07 \\
\hline-17 & -0.28 & -0.62 & -1.24 & -0.65 & +13 & -0.59 & -1.31 & -0.71 & -0.42 \\
\hline-16 & -0.37 & -0.83 & -1.62 & -0.87 & +14 & 0.04 & 0.08 & -0.67 & -0.39 \\
\hline-15 & -0.17 & -0.38 & -1.79 & -0.99 & +15 & 0.01 & 0.01 & -0.66 & -0.37 \\
\hline-14 & 0.22 & 0.49 & -1.57 & -0.90 & +16 & 0.36 & 0.80 & -0.31 & -0.17 \\
\hline-13 & -0.20 & -0.45 & -1.77 & -1.05 & +17 & -0.18 & -0.39 & -0.48 & -0.25 \\
\hline-12 & -0.41 & -0.92 & -2.18 & -1.35 & +18 & -0.81 & -1.81 & -1.30 & -0.66 \\
\hline-11 & 0.19 & 0.42 & -1.99 & -1.28 & +19 & -0.68 & -1.51 & -1.98 & -0.98 \\
\hline-10 & 0.04 & 0.08 & -1.96 & -1.31 & +20 & -0.06 & -0.13 & -2.03 & -0.99 \\
\hline-9 & -0.09 & -0.20 & -2.05 & -1.44 & +21 & -0.15 & -0.33 & -2.18 & -1.04 \\
\hline-8 & -0.30 & -0.67 & -2.35 & -1.74 & +22 & -0.01 & -0.02 & -2.19 & -1.02 \\
\hline-7 & -0.81 & -1.81 & -3.16 & -2.49 & +23 & 0.35 & 0.79 & -1.84 & -0.83 \\
\hline-6 & 0.24 & 0.53 & -2.92 & -2.46 & +24 & 0.34 & 0.76 & -1.49 & -0.67 \\
\hline-5 & 0.32 & 0.72 & -2.60 & -2.36 & +25 & -0.38 & -0.85 & -1.88 & -0.82 \\
\hline-4 & 0.11 & 0.24 & -2.49 & -2.48 & +26 & 0.44 & 0.97 & -1.44 & -0.62 \\
\hline-3 & 0.17 & 0.37 & -2.33 & $-2.59^{*}$ & +27 & 0.02 & 0.03 & -1.43 & -0.60 \\
\hline-2 & -0.38 & -0.85 & -2.71 & $-3.48^{*}$ & +28 & -0.03 & -0.07 & -1.46 & -0.60 \\
\hline-1 & -1.01 & -2.25 & -3.72 & $-5.85^{* *}$ & +29 & -0.01 & -0.02 & -1.47 & -0.60 \\
\hline 0 & 1.02 & 2.28 & -2.70 & $-6.00^{* *}$ & +30 & -0.86 & -1.92 & -2.33 & -0.93 \\
\hline \multicolumn{10}{|c|}{${ }^{*}$ Calculated t-value significant at $\mathrm{p}=0.05 * *$ Calculated $\mathrm{t}$-value significant at $\mathrm{p}=0.01$} \\
\hline & & & & 101 & 10 & MS-E & & & \\
\hline
\end{tabular}

The CAARs in table 4 (previous page) have been negative throughout the event window of 61 days. While the CAARs are significant on only 3 days during the pre-event day period, 28 significant CAARs can be noticed during the post-event day period. The CAAR on event day is also significant. The CAARs are significant at $1 \%$ level on $t-1$, to to $t+6$ and $t+14$ to $t+20$ and for the rest of the days they are significant at $5 \%$ level. It is evident from the results that the mergers and acquisitions have yielded negative returns on the shares of the acquiring banks. Similar results have been found in Sachdeva, Sinha \& Kaushik (2015) who found that the 25 days and 40 days CARs have been significantly negative for the acquiring firms and created no shareholder's wealth; Adnan \& Hossain (2016) who found that the post-announcement period prices downgraded for the acquiring firms with higher fluctuations as compared to the targets; and Chen, Ramaya \& Wu (2019) where the returns for the bond and shareholders of the bidding 
firms have been negative. Negative and significant results a few days before the event day may suggest information leakage in the market or as a result of anticipation. Similar evidences are found in Adnan \& Hossain (2016) and Yilmaz \& Tanyeri (2018) who claim the possibilities of information leakages in emerging markets.

\begin{tabular}{|c|c|c|c|c|c|c|c|c|c|}
\hline \multicolumn{10}{|c|}{ Table 6: Daily AARs, CAARs and test statistics during the Event Window } \\
\hline \multicolumn{10}{|c|}{$(-30$ to +30$)$ for the Entire Sample } \\
\hline Days & AAR & $\mathrm{t}_{A A R}$ & CAAR & $\mathrm{t}_{C A A R}$ & Days & AAR & $\mathrm{t}_{A A R}$ & CAAR & $\mathrm{t}_{C A A R}$ \\
\hline-30 & -0.28 & -0.57 & -0.28 & -0.02 & 0 & 0.88 & 1.78 & -3.87 & $-7.87^{* *}$ \\
\hline-29 & -0.20 & -0.40 & -0.47 & -0.03 & +1 & -2.56 & $-5.21 * *$ & -6.43 & $-6.54^{* *}$ \\
\hline-28 & 0.63 & 1.28 & 0.16 & 0.01 & +2 & 0.21 & 0.44 & -6.21 & $-4.21^{* *}$ \\
\hline-27 & 0.31 & 0.63 & 0.47 & 0.03 & +3 & -0.02 & -0.04 & -6.23 & $-3.17^{* *}$ \\
\hline-26 & -1.05 & -2.13 & -0.58 & -0.04 & +4 & -0.52 & -1.05 & -6.75 & $-2.75^{*}$ \\
\hline-25 & -0.45 & -0.92 & -1.03 & -0.08 & +5 & 0.72 & 1.47 & -6.03 & -2.04 \\
\hline-24 & -0.19 & -0.39 & -1.22 & -0.10 & +6 & 1.05 & 2.14 & -4.98 & -1.45 \\
\hline-23 & -0.08 & -0.17 & -1.31 & -0.11 & +7 & 0.43 & 0.87 & -4.55 & -1.16 \\
\hline-22 & 0.62 & 1.27 & -0.68 & -0.06 & +8 & $\begin{array}{l}-0.18 \\
\end{array}$ & -0.36 & -4.73 & $\begin{array}{l}-1.07 \\
\end{array}$ \\
\hline-21 & -0.36 & -0.73 & -1.04 & $\begin{array}{l}-0.10 \\
\end{array}$ & +9 & 0.91 & 1.84 & -3.82 & $\begin{array}{l}-0.78 \\
\end{array}$ \\
\hline-20 & -0.44 & -0.90 & -1.48 & -0.14 & +10 & 0.05 & 0.11 & -3.77 & -0.70 \\
\hline-19 & 0.34 & 0.68 & -1.14 & -0.12 & +11 & 0.07 & 0.15 & -3.69 & -0.63 \\
\hline-18 & $\begin{array}{l}-0.08 \\
\end{array}$ & -0.17 & -1.23 & -0.13 & +12 & 0.21 & 0.42 & \begin{tabular}{|l|}
-3.49 \\
\end{tabular} & -0.55 \\
\hline-17 & 0.62 & 1.27 & -0.60 & -0.07 & +13 & -2.09 & $-4.25^{* *}$ & -5.57 & -0.81 \\
\hline-16 & -0.25 & -0.52 & -0.86 & -0.10 & +14 & -0.95 & -1.94 & -6.53 & -0.89 \\
\hline-15 & -0.71 & -1.45 & -1.57 & -0.20 & +15 & \begin{tabular}{|l|}
-0.19 \\
\end{tabular} & $\begin{array}{l}-0.39 \\
\end{array}$ & -6.72 & -0.85 \\
\hline-14 & -0.65 & $\begin{array}{l}-1.32 \\
\end{array}$ & $\begin{array}{l}-2.22 \\
\end{array}$ & $\begin{array}{l}-0.30 \\
\end{array}$ & +16 & $\begin{array}{l}-0.17 \\
\end{array}$ & -0.35 & $\begin{array}{l}-6.89 \\
\end{array}$ & $\begin{array}{l}-0.82 \\
\end{array}$ \\
\hline $\begin{array}{l}-13 \\
\end{array}$ & -0.51 & -1.04 & $\begin{array}{l}-2.73 \\
\end{array}$ & -0.40 & +17 & -0.45 & -0.92 & -7.34 & $\begin{array}{l}-0.83 \\
\end{array}$ \\
\hline-12 & 0.35 & 0.71 & $\begin{array}{l}-2.38 \\
\end{array}$ & -0.37 & +18 & -0.39 & -0.80 & -7.73 & -0.83 \\
\hline-11 & $\begin{array}{l}-0.23 \\
\end{array}$ & -0.46 & $\begin{array}{l}-2.61 \\
\end{array}$ & -0.44 & +19 & $\begin{array}{l}-1.28 \\
\end{array}$ & $-2.61^{*}$ & $\begin{array}{l}-9.02 \\
\end{array}$ & -0.92 \\
\hline-10 & 0.91 & 1.85 & -1.70 & -0.31 & +20 & -0.12 & -0.25 & -9.14 & -0.89 \\
\hline-9 & -0.49 & -0.99 & $\begin{array}{l}-2.19 \\
\end{array}$ & -0.44 & +21 & 0.97 & 1.97 & -8.17 & -0.76 \\
\hline-8 & -0.94 & -1.91 & -3.12 & -0.71 & +22 & 0.55 & 1.13 & -7.62 & -0.67 \\
\hline $\begin{array}{l}-7 \\
\end{array}$ & -0.83 & -1.69 & -3.95 & -1.01 & +23 & -0.10 & -0.21 & -7.72 & -0.65 \\
\hline-6 & 0.04 & 0.07 & -3.92 & -1.14 & +24 & -0.14 & $\begin{array}{l}-0.29 \\
\end{array}$ & -7.86 & -0.64 \\
\hline-5 & 0.47 & 0.95 & -3.45 & -1.17 & +25 & -0.64 & -1.30 & -8.50 & -0.67 \\
\hline-4 & $\begin{array}{l}-0.02 \\
\end{array}$ & -0.03 & -3.47 & -1.41 & +26 & $\begin{array}{l}-0.06 \\
\end{array}$ & -0.12 & -8.56 & $\begin{array}{l}-0.65 \\
\end{array}$ \\
\hline-3 & 0.74 & 1.51 & $\begin{array}{l}-2.73 \\
\end{array}$ & $\begin{array}{l}-1.39 \\
\end{array}$ & +27 & 0.09 & 0.19 & -8.47 & -0.62 \\
\hline-2 & $\begin{array}{l}-1.01 \\
\end{array}$ & $\begin{array}{l}-2.05 \\
\end{array}$ & \begin{tabular}{|l|}
-3.74 \\
\end{tabular} & $-2.53^{*}$ & +28 & \begin{tabular}{|l|l|}
-0.11 \\
\end{tabular} & $\begin{array}{l}-0.23 \\
\end{array}$ & -8.58 & $\begin{array}{l}-0.60 \\
\end{array}$ \\
\hline-1 & -1.01 & -2.05 & -4.74 & $-4.83^{* *}$ & +29 & -0.39 & -0.80 & -8.98 & -0.61 \\
\hline 0 & 0.88 & 1.78 & -3.87 & $-7.87^{* *}$ & +30 & -0.45 & -0.92 & -9.43 & -0.62 \\
\hline \multicolumn{10}{|c|}{ gnifif } \\
\hline & & & & & & & & & \\
\hline
\end{tabular}

3.3. Average abnormal returns of banks listed in the NYSE. The daily AARs, CAARs and test statistics for the US banks are depicted in table 5 (previous page). Negative AARs are reflected on 17 days in the pre-event day period and 15 days in the post-event day period. However, none of them are significant. The CAARs are negative from the day t-18 and have been negative on all the days till $t+30$ except on $t+9$. Significant CAARs are seen on all the days through $t-3$ to $t+2$. Although the abnormal returns are negative in the event window, they are not significant. However, significant CAARs a few days before and after the announcement day indicate that the market reacted to the event and that the event has impacted the returns on the shares of the US acquiring banks. 
The results in table 4 and 5 indicate that the returns on the shares of the acquiring banks in India have been impacted more than those of the acquiring banks in the US. However, the overall returns in both the developed as well as the emerging market has been negative; though more significant in the emerging market. However, our inference is contrary to Yilmaz \& Tanyeri (2018) as we found higher CAARs in emerging market as compared to the developed market.

3.4. Average abnormal returns of the entire sample of events. The results of the event study conducted by clustering all the 14 events together are presented in table 6 (previous page). The AARs are negative for 20 days during the prevent day period and 19 days during the post-event day period. The AAR on the announcement day is positive. No significant AARs during the t-30 to t0 period have been noticed but significant AARs on 3 days during the post-event day period have been noticed. While the AARs on $t+1$ and $t+13$ are significant at $1 \%$ level the AAR on $\mathrm{t}+19$ is significant at $5 \%$ level.

The CAARs are negative on all the days except t-28 and t-27. Significant CAARs are seen on all the days through $t-2$ to $t+4$. The CAARs are significant at $1 \%$ level on $t-1$ to $t+3$ and $5 \%$ level on $t-2$ and $t+4$. Negative and significant CAARs few days around the event day indicate that the merger and acquisition announcements significantly impacted the returns on the shares of the acquiring banks. The shareholders of the acquiring banks experienced negative CAARs throughout the event window.

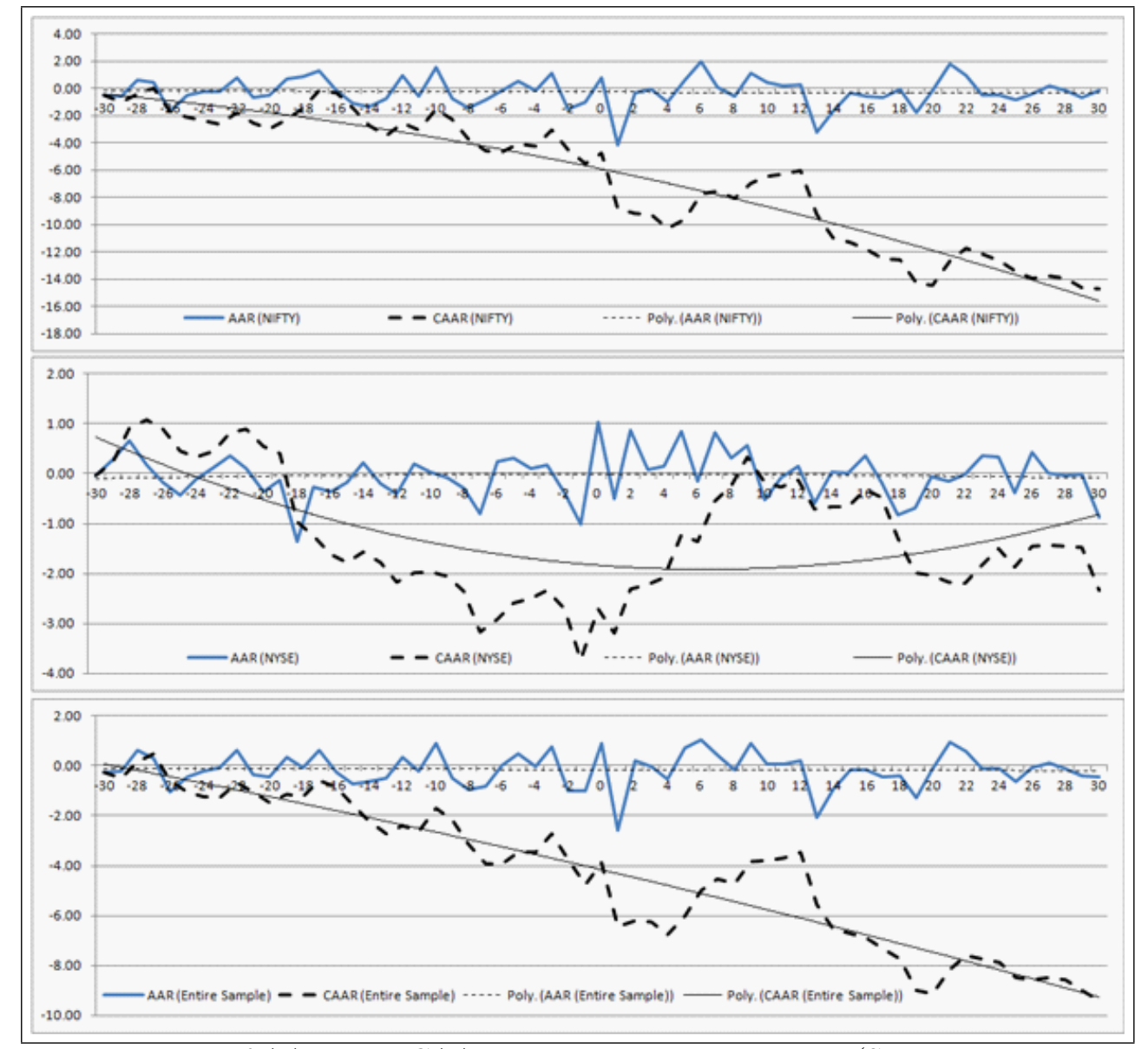

Figure 2: Trend of AARs and CAARs during the event window (Source: Based on the author's calculations in MS-Excel) 
3.5. Trend of AARs and CAARs in the event window. Figure 2 (above) is the graphical presentation of the AARs and CAARs of the acquiring banks. A downward trend since beginning could be seen in the case of the Indian banks and the entire sample CAARs. However, the trend in the CAARs of the US banks though downward from day t-24, is seen recovering itself moving upward from the event day onwards, however, reversing the trend day $t+10$ onwards. The CAARs of the Indian and US banks follow an opposite trend contrary to each other. There exists a difference in the reaction of both markets to the merger and acquisition announcement news. Indian stock market, an emerging market, anticipated the news and negative returns on almost all the days through the event window is noticed indicating semi-strong efficiency as in Gopalaswamy, Acharya \& Malik (2008). On the contrary, the US stock market, a developed market, reacted differently. Few days around the event day are significant but later the market differentiated itself from the abnormal reaction. The trend in AARs of both the markets are also opposite, although a flat trend line in both cases.

3.6. Analysis of the AARs and CAARs in the shorter event window period. The results of the analysis of the shorter window period are reflected in table 7 . The test statistics for shorter window periods ranging from 3 days, 7 days to 15 days have been calculated. The test statistic is significant only for the CAAR in the $t-1$ to $t+1$ window period in case of Indian banks while none of them are significant for the US banks. The CAARs are significant in the $t-1$ to $t+1$ and $t-3$ to $t+3$ windows for the entire sample. Hence, it can be concluded that the impact of the merger announcements are significant in shorter windows of up to 7 days. However, for the US banks, the abnormal returns are not significant and that for the Indian banks only the 3 days window period CAAR has been significant.

Now that the significant CAARs have been found few days around the event day for the entire sample and the impacts of the merger announcements have been established, though more negative and significant in case of Indian banks, in the next section the significance of AARs and CAARs in the post-event window period has been tested.

\begin{tabular}{|c|c|c|c|c|c|c|}
\hline \multicolumn{2}{|c|}{ Table 7: Test statistics around the announcement dates } \\
\hline Window Period & -1 to +1 & & -3 to +3 & & -7 to +7 & \\
\hline & $\mathrm{t}_{A A R}$ & $\mathrm{t}_{C A A R}$ & $\mathrm{t}_{A A R}$ & $\mathrm{t}_{C A A R}$ & $\mathrm{t}_{A A R}$ & $\mathrm{t}_{C A A R}$ \\
\hline NIFTY & -1.83 & $-3.18^{*}$ & -0.91 & -2.41 & -0.32 & -1.26 \\
\hline NYSE & -0.36 & -0.62 & 0.09 & 0.23 & 0.27 & 1.04 \\
\hline ENTIRE SAMPLE & -1.83 & $-3.62^{*}$ & -0.80 & $-2.56^{*}$ & -0.19 & -1.61 \\
\hline \multicolumn{7}{|c|}{ Source: Author's calculations in MS-Excel } \\
\hline
\end{tabular}

3.7. Post-event window period performance. The post-event window period performance is measured through the AARs, CAARs and test statistics for the $t+31$ to $t+50$ days period to determine whether in the post-event-window period the impact has been similar or different. The test statistics are presented in table 8. No significant AARs in this period is noticed for the Indian banks, however, 6 and 2 significant AARs are available for the US banks and the entire sample respectively during this period. The CAARs of the Indian acquiring banks have continued the trend of significance for 11 days in the post-event-window period. The CAAR on day $t+35$ is significant for the US banks while no CAAR is found significant for the entire sample.

The number of positive AARs in the post-event window period is almost the same for all the categories but positive and significant AARs of US banks as compared to negative and insignificant AARs of Indian banks. It is evident from the statistical results that the stocks of the Indian banks have experienced negative and significant abnormal returns in the post-event window period as compared to the non-significant abnormal returns of the US banks. 


\begin{tabular}{|c|c|c|c|c|c|c|}
\hline \multicolumn{6}{|c|}{ Table 8 Test statistics for the post-event window period $(\mathrm{t}+31$ to $\mathrm{t}+50)$} \\
\hline Days & $\mathrm{t}_{A A R}$ & $\mathrm{t}_{A A R}$ & $\mathrm{t}_{A A R}$ & $\mathrm{t}_{C A A R}$ & $\mathrm{t}_{C A A R}$ & $\mathrm{t}_{C A A R}$ \\
\hline & $(\mathrm{NIFTY})$ & $(\mathrm{NYSE})$ & & $($ NIFTY) & $(\mathrm{NYSE})$ & \\
\hline+31 & -0.47 & $-2.89^{*}$ & -1.57 & $-3.38^{*}$ & -1.43 & -0.65 \\
\hline+32 & 1.97 & -0.14 & 1.76 & $-2.98^{*}$ & -1.43 & -0.58 \\
\hline+33 & 0.35 & -2.25 & -0.56 & $-2.88^{*}$ & -1.80 & -0.57 \\
\hline+34 & -0.64 & -1.27 & -1.09 & $-2.94^{*}$ & -1.99 & -0.59 \\
\hline+35 & 1.58 & $-4.54^{* *}$ & -0.32 & $-2.64^{*}$ & $-2.71^{*}$ & -0.58 \\
\hline+36 & 0.07 & 0.75 & 0.36 & $-2.59^{*}$ & -2.56 & -0.56 \\
\hline+37 & -1.19 & -0.64 & -1.34 & $-2.75^{*}$ & -2.62 & -0.58 \\
\hline+38 & 2.85 & $7.16^{* *}$ & $5.42^{* *}$ & -2.26 & -1.44 & -0.42 \\
\hline+39 & 0.44 & 2.08 & 1.22 & -2.16 & -1.10 & -0.38 \\
\hline+40 & 1.83 & $3.51^{*}$ & $3.06^{* *}$ & -1.85 & -0.54 & -0.30 \\
\hline+41 & -0.15 & 0.05 & -0.12 & -1.85 & -0.52 & -0.29 \\
\hline+42 & -1.88 & 0.28 & -1.62 & -2.11 & -0.47 & -0.32 \\
\hline+43 & -0.09 & $-4.37^{* *}$ & -1.80 & -2.10 & -1.13 & -0.36 \\
\hline+44 & -1.12 & $-3.12^{*}$ & -2.25 & -2.25 & -1.58 & -0.40 \\
\hline+45 & -1.34 & -1.17 & -1.69 & $-2.42^{*}$ & -1.73 & -0.43 \\
\hline+46 & -0.07 & 2.10 & 0.75 & $-2.40^{*}$ & -1.41 & -0.40 \\
\hline+47 & -2.12 & -0.03 & -1.96 & $-2.68^{*}$ & -1.40 & -0.44 \\
\hline+48 & -0.48 & 1.53 & 0.15 & $-2.73^{*}$ & -1.17 & -0.42 \\
\hline+49 & 1.36 & 1.99 & 2.03 & $-2.51^{*}$ & -0.87 & -0.37 \\
\hline+50 & 1.74 & 0.30 & 1.72 & -2.24 & -0.82 & -0.33 \\
\hline$*$ Calculated $\mathrm{t}-$ value significant at $\mathrm{p}=0.05 * *$ & Calculated $\mathrm{t}-\mathrm{value} \mathrm{significant} \mathrm{at} \mathrm{p}=0.01$ \\
\hline & & Source: Author's calculations in MS-Excel & \\
\hline
\end{tabular}

\section{Conclusion and implications}

With a sample size of 14 acquiring banks, we examined the stock price reaction to merger and acquisition announcement news using the standard event study method by Brown \& Warner $(1980 ; 1985)$. It is evident from the statistical inferences that such news does impact the stock price reaction in the form of generating some abnormal returns around the announcement date. In our study, the impact has been significantly negative as also found in Sachdeva, Sinha \& Kaushik (2015), Adnan \& Hossain (2016) and Chen, Ramaya \& Wu (2019). However, different markets react differently. In our study, we found the reaction of the share prices of Indian banks to be more sensitive as compared to those of US banks. While the Indian bank's shares have continued to have significant CAARs throughout the event window and the post-eventwindow period, the CAARs of the US banks have been significant for a few days around the announcement date. Our study draws similar inference of semi-strong efficiency of the Indian stock market as in Gopalaswamy, Acharya \& Malik (2008).

This study anticipates filling the gap in the event study literature and supporting the evidence of previous studies. The inferences drawn in this study will help the management plan mergers and acquisitions strategically and the investors in accumulating abnormal gains due to the share price movements motivated by merger news. This study lacks examining the post-merger share price behaviour. Further study may focus on generating evidence to check whether the post-merger returns are similar to those around the announcement date (as in Oler, Harrison \& Allen, 2008; Duso, et. al., 2010; and, Sachdeva, Sinha \& Kaushik 2015).

\section{REFERENCES}

[1] Adnan, ATM., \& Hossain, A. (2016). Impact of M\&A announcement on acquiring and target firm's stock price: an event analysis approach. International Journal of Finance and Accounting, 5(5), 228-232. doi: 10.5923/j.ijfa.20160505.02. 
[2] Antoniadis, I., Alexandridis, A. \& Sariannidis, N. (2014). Mergers and acquisitions in the Greek banking sector: An event study of a proposal. Procedia Economics and Finance, 14, 13-22. doi: 10.1016/S22125671(14)00680-7.

[3] Big bank mergers: Government turns ten PSBs into four (2019, September 2), The Economic Times. Retrieved from: https://economictimes.indiatimes.com/news/economy/policy/big-bank-mergers-governmentturns-ten-psbs-into-four/articleshow/70918585.cms.

[4] Brown, S. J., \& Warner, J. B. (1980). Measuring security price performance. Journal of Financial Economics, 8(3), 205-258. Retrieved from http://citeseerx.ist.psu.edu/viewdoc/download?doi=10.1.1.553.4024\&rep=rep1\&type=pdf.

[5] Brown, S. J., \& Warner, J. B. (1985). Using daily stock returns, the case of event studies. Journal of Financial Economics, 14(1), 3-31. Retrieved from http://leeds-faculty.colorado.edu/bhagat/brownwarner1985.pdf.

[6] Campa, J. M., \& Hernando, I. (2005). M\&As performance in the European financial industry. Journal of Banking \& Finance, 30(12), 3367-3392. Retrieved from https://scihub.bban.top/https://doi.org/10.1016/j.jbankfin.2006.06.006.

[7] Chen, F., Ramaya, K. \& Wu, W. (2019). The wealth effects of merger and acquisition announcements on bondholders: new evidence from the over-the-counter market. Journal of Economics and Business. https://doi.org/10.1016/j.jeconbus.2019.105862.

[8] Diaw, A. (2011). The effect of mergers and acquisitions on shareholder wealth: the case of European banks. First International Conference of Cost Action IS0902, Systemic Risks, Financial Crises, and Credit, COST, May 2011, Saint-Denis, France. hal-01184673. Retrieved from https://hal.archives-ouvertes.fr/hal01184673 document.

[9] Duso, T., Gugler, K., \& Yurtoglu, B. (2010). Is the event study methodology useful for merger analysis? A comparison of stock market and accounting data. International Review of Law and Economics, 30, 186-192. Retrieved from https://www.wu.ac.at/fileadmin/wu/d/i/iqv/Gugler/Artikel/dgy_irle.pdf.

[10] Farinos, J. E., Herrero, B., \& Latorre, M. A. (2019). Market valuation and acquiring firm performance in the short and long term: Out-of-sample evidence from Spain. BRQ Business Research Quarterly. https://doi.org/10.1016/j.brq.2019.01.001.11.

[11] Gopalaswamy, A. K., Acharya, D. \& Malik, J. (2008). Stock price reaction to merger announcements: an empirical note on Indian markets. Investment Management and Financial Innovations, 5(1), 95-103. Retrieved from: https://www.researchgate.net/publication/312592785_Impact_of_MA_Announcement_on_Acquiring _ and_Target_Firm's_Stock_Price_An_Event_Analysis_Approach.

[12] Graca, T., \& Masson, R. (2016). A structural event study for M\&As: an application in corporate governance. Applied Economics, DOI:10.1080/00036846.2016.1156237.

[13] Henry, D. \& Mendonca, J. (2012, August 27). Reutors. Retrieved from: https://www.reuters.com/article/us-hudsoncity-offer/mt-bank-to-buy-hudson-city-bancorp-in-3-7-billiondeal-idUSBRE87Q0GL20120827.

[14] ICICI Bank to buy Bank of Rajasthan (2010, May, 18). Livemint. Retrieved from: https://www.livemint.com/Home-Page/D2f0qaXoo4P0NEiO4HcSuN/ICICI-Bank-to-buy-Bank-ofRajasthan.html.

[15] KeyCorp to Acquire First Niagara Financial Group (2015, October 30). Key Bank (Press Release). Retrieved from: http://investor.key.com/Cache/IRCache/48cd3072-7004-bfb5-4d1dda9b655339d2.PDF? $=\mathrm{PDF} \& \mathrm{~T}=\& \mathrm{Y}=\& \mathrm{D}=\& \mathrm{FID}=48 \mathrm{~cd} 3072-7004-\mathrm{bfb} 5-4 \mathrm{~d} 1 \mathrm{~d}-\mathrm{da} 9 \mathrm{~b} 655339 \mathrm{~d} 2 \& \mathrm{iid}=100334$.

[16] Kotak Mahindra Bank to acquire ING Vysya in all-stock deal (2014, November 27). Livemint. Retrieved from: https://www.livemint.com/Companies/d3JEmWoM4ZxUc31WRDOA6O/Kotak-MahindraBank-to-acquire-ING-Vysya.html.

[17] Kumara, N. R., Vidhya, VJ., \& Reddy, M. B. (2019). A study on the impact of pre and post bank merger announcement on stock price movement. International Journal of Research and Analytical Reviews, 6(1), 995-1001. Retrieved from http://www.ijrar.org/papers/IJRAR19J1788.pdf.

[18] Levitt, H. (2019, February, 7). BB\&T to Buy SunTrust in Biggest Bank Merger in a Decade. Bloomberg. Retrieved from: https://www.bloomberg.com/news/articles/2019-02-07/bb-t-and-suntrust-banks-agree-tocombine.

[19] Merle, R. (2011, June, 16). Capital One Bank to acquire ING Direct USA, The Washington Post. Retrieved from: https://www.washingtonpost.com/business/economy/capital-one-bank-to-acquire-ing-directusa/2011/06/16/AG4fVzXH_story.html.

[20] Oler, D. K., Harrison, J. S. \& Allen, M. R. (2008). The danger of misinterpreting short-window event study findings in strategic management research: an empirical illustration using horizontal acquisitions. Strategic Organization, 6(2), 151-184. Doi: 10.1007/s11156-013-0385-5.

[21] Perepeczo, A. (2007). Event study in the evaluation of the effects of mergers and acquisitions. Folia Oeconomica Stetinensia, 6(1), 107-122. Retrieved from: https://ideas.repec.org/a/vrs/foeste/v6y2007i1p107122n7.html\#download. 
[22] PNC Announces Agreement to Buy RBC Bank (USA) (2011, June 20). PR Newswire. Retrieved from: https://www.prnewswire.com/news-releases/pnc-announces-agreement-to-buy-rbc-bank-usa124176974.html.

[23] Rahman, Z., Ali, A., \& Zebran, K. (2018). The effects of mergers and acquisitions on stock price behavior in banking sector of Pakistan. The Journal of Finance and Data Science, 4, 44-54. Retrieved from http://iranarze.ir/wp-content/uploads/2018/09/E9188-IranArze.pdf.

[24] Sachdeva, T., Sinha, N., \& Kaushik, K. P. (2015). Impact of merger and acquisition announcement on shareholders' wealth an empirical study using event study methodology. Delhi Business Review, 16(2), 19-36. Retrieved from http://www.delhibusinessreview.org/V16n2/dbr_v16n2c.pdf.

[25] SBI Proposes Merger of Five Associate Banks, BMB, Unions Protest (2016, May 16), Outlook India. Retrieved from: https://www.outlookindia.com/newswire/story/sbi-proposes-merger-of-five-associate-banksbmb-unions-protest/940384.

[26] Selcuk, E.A. (2015). Do mergers and acquisitions create value for Turkish target firms? an event study analysis. Procedia Economics and Finance, 30, 15-21. Retrieved from https://ideas.repec.org/p/sek/iefpro/2204990.html\#download.

[27] Shah \& Arora (2014). M\&A Announcements and Their Effect on Return to Shareholders: An Event Study. Accounting and Finance Research, 3(2), 170-190. Retrieved from http://www.sciedu.ca/journal/index.php/afr/article/download/4684/2805.

[28] Shah, A. \& Deo, M. (2013). Bank mergers and shareholder value creation in India. International Journal of Business and Society, 14(2), 245 - 264 . Retrieved from http://www.ijbs.unimas.my/repository/pdf/Vol14No2paper6.pdf.

[29] Song, M. H., \& Walkling, R. A. (2000). Abnormal returns to rivals of acquisition targets: A test of the acquisition probability hypothesis. Journal of Financial Economics, 55(2), 143-171. Retrieved from https://scihub.bban.top/https://doi.org/10.1016/S0304-405X(99)00048-3.

[30] Sylvani, N. F., \& Yunita, I. (2017). Market reactions toward mergers and acquisitions announcement in telecommunication firms listed in Asia-pacific stock markets. International Journal of Management and Applied Science, 3(5), 14-18. Retrieved from http://www.iraj.in/journal/journal_file/journal_pdf/14-369150035525714-18.pdf.

[31] Vijaya Bank, Dena Bank, BoB to merge: Govt (2018, September, 17), The Hindu Business Line. Retrieved from: https://www.thehindubusinessline.com/money-and-banking/vijaya-bank-dena-bank-bob-tomerge-govt/article24968935.ece.

[32] Wilcox, H. D., Chang, K. C. \& Grover, V. (2001). Valuation of mergers and acquisitions in the telecommunications industry: a study on diversification and firm size. Information \& Management, 32, 459-471. Retrieved from https://sites.uark.edu/wp-content/uploads/2017/06/2001-IandM1.pdf.

[33] Wilmington Trust to Merge with M\&T Bank Corporation (2010, November 1), PR Newswire. Retrieved from: https://www.prnewswire.com/news-releases/wilmington-trust-to-merge-with-mt-bank-corporation106436898.html.

[34] Yilmaz, I. S., \& Tanyeri, B. (2018). Global Merger and Acquisition (M\&A) activity: 1992-2011. Finance Research Letters, 17, 110-117. Retrieved from http://basak.bilkent.edu.tr/Isil2018.pdf. 